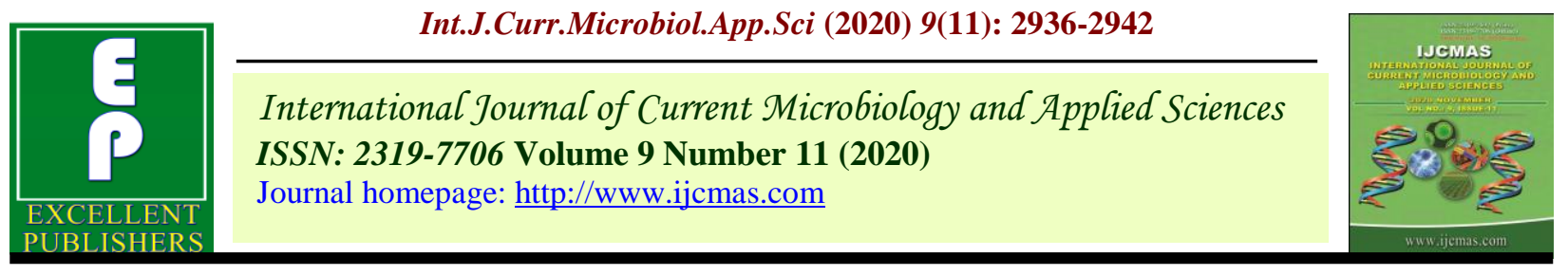

Original Research Article

https://doi.org/10.20546/ijcmas.2020.911.357

\title{
Development of Solar Operated Hydroponic Fodder Production System
}

\author{
H. M. Manju, Manjeet Singh*, K. K. Yadav and S. R. Bhakar \\ Department of Soil and Water Engineering, CTAE, MPUAT, Udaipur, India \\ *Corresponding author
}

K e y w o r d s
$\begin{aligned} & \text { Hydroponics, } \\ & \text { Automation, Crude } \\ & \text { protein, Crude fiber, } \\ & \text { Arduino, Solar } \\ & \text { power }\end{aligned}$
Article Info
$\begin{aligned} & \text { Accepted: } \\ & 20 \text { October } 2020 \\ & \text { Available Online: } \\ & 10 \text { November } 2020\end{aligned}$

Keywords

Hydroponics, Automation, Crude protein, Crude fiber, Arduino, Solar Article Info

Accepted: Available Online: 10 November 2020

\section{A B S T R A C T}

The study was conducted with view of establishment technology of production and to reduce the scarcity of fodder to the livestock. A solar operated hydroponic system was designed in the area $150 \mathrm{ft}^{2}$ with bamboo sticks and shade net at the Technology Park, CTAE, Udaipur. Unit consist of 4 shelves with bamboo stand having production capacity of $30 \mathrm{~kg}$ per day. Plastic trays were used for fodder production, automatic irrigation system controlled with Arduino and solar panel with battery buckup used for power supply. The $10^{\text {th }}$ day fodder was harvested and laboratory test were carried out to study the content of crude protein, crude fibre, Ether extract and total ash. Three Maize seed rates were selected for the chemical analysis i.e. $600 \mathrm{~g}, 750 \mathrm{~g}, 900 \mathrm{~g}$ per tray. Test shows that highest crude protein and ether extract was observed in $900 \mathrm{~g} /$ tray hydroponic fodder $14.81 \%, 3.01 \%$ respectively.

\section{Introduction}

In India, livestock plays an important role for the nutritional security, particularly of the small and marginal farmers. As per the $20^{\text {th }}$ livestock census 2019, total cattle population in the country is 192.49 million (Anonymous 2019). Total cattle population is increased by $0.8 \%$ over previous livestock census 2012. In Rajasthan it was 13.3 million cattle population during 2012 now 13.9 million cattle population. There is change of $4.41 \%$ in these five years (RLDB $20^{\text {th }}$ livestock census 2019).The increase in the livestock population along with the intensive rearing system has resulted in the increase demands for feeds and fodder in the country. The feed scarcity has been the main limiting factor in improving the livestock productivity. The land allocation for cultivation of green fodder is limited to only $5 \%$ of the gross cropped area; but by 2020 , India would require a total 526,855 and 56 million tons of dry matter, green fodder and concentrates respectively 
(Ramteke et al., 2019). To overcome from this situation and decreasing of water use in agriculture and to increase the green fodder production by using less amount of water some methods and technologies were needed that can contribute to improved water use efficiency and productivity. The conventional method for fodder production needs more land to produce and it dependent on the seasonal or weather conditions with long time period of growing, more use of water so a requisite need of a technique which can reduces the land need and water use, with less days of production. Through which the only available land will use by human for the food and income and also the feeding requirement of the livestock will maintain and the productivity survival life will also increase. There are several techniques are design to overcome this situation.

A novel method called 'Hydroponics' which means growing plants without soil by using nutrient water at desired temperature and humidity (Jemimah et al., 2015). The word hydroponics comes from two Greek words 'hydro' and 'phonics' which means water and working respectively (Reddy et al., 2012).

Solar energy can be more important to India's plan not only to integrate new capacity but also to maximize energy security and address environmental concerns, and lead valuable market for renewable energy (Sharma et al., 2012). Solar operated hydroponic fodder production system requires less maintenance, irrigation is fully on automation. The major cause of electricity supply in many villages continuous electricity supply is not provided; in hydroponic system irrigation is done periodically to maintain humidity and temperature. If electricity not supplied properly green fodder gets dry and affected by fungus (Kamat et al., 2018). The fungus is dangerous for the cattle health. Though solar is used only day time, the battery had backup capacity of 13 days, hence solar operated hydroponic fodder production system developed and performed at CTAE, Udaipur.

\section{Materials and Methods}

The experimental was carried out at the Technology Park, CTAE campus, MPUAT Udaipur. The study area, Udaipur is situated on longitude $73^{\circ} 42^{\prime}$ and latitude of $24^{\circ} 35^{\prime}$ and at an elevation of 582.17 meters above mean sea level. The farm area is characterized by sub humid climate with an average annual rainfall is $641 \mathrm{~mm}$, mostly received during monsoon season (June to September). The maximum temperature goes as high as $46^{\circ} \mathrm{C}$ during summer and minimum as low as $5^{\circ} \mathrm{C}$ during winter months.

\section{Shade net house}

A shade net house was constructed with the locally available bamboo. The dimensions of shade net house are 15 feet length $\mathrm{x} 10$ width x 10 feet height in the middle and 8feet height in the corners. The dimension of door is $6 f e e t$ $\mathrm{x} 3$ feet. Door is also made of bamboo sticks. After the construction of frame structure of bamboo house, it is covered with green colour shade net of $60-80 \%$ UV treated so which could resist the much sunrays which directly fall on the green fodder.

\section{Bamboo framed hydroponic stand}

A bamboo framed hydroponic stand was made of bamboo sticks. Average diameter of bamboo sticks were $7.5 \mathrm{~cm}$. Dimensions of stand was of length 8.6 feet $\mathrm{x}$ width 4.9 feet and height of 7 feet. This stand has four compartments in it to place the hydroponic trays. The gap between first three compartments was of 2.3 feet each from the bottom. This structure was fixed into the ground. The isometric view of hydroponic stand and shade net house shown in Fig. 1 and 2. The life span of this bamboo hydroponic stand around 5-6 years. In each stand of this 
structure had space that can hold around 12 hydroponic trays. All sticks were tied with a steel wire and fixed by using nails. The Shade net house and bamboo framed hydroponic stand with hydroponic trays shown in Fig. 3.

\section{Power transmission system}

Solar panel $80 \mathrm{~W}$ was installed on the top of the shade net house and it was connected with solar charge controller. From solar charge controller both positive and negative terminal of the 40Ah battery was connected to it to recharge from the solar panel and supplies the electricity to the pump, solenoid valves, relay switch and Arduino module (Aruna et al., 2018). Positive terminal wire of the Motor pump was connected with load port of the solar charge controller and other negative terminal wire connected with relay switch. Solenoid valves connection were alike motor pump connection. All the negative terminals of the control system made common. Arduino module was connected with the controller through USB cable and it connects with the relay switch regulate the functioning of solenoid valves and pump according to the programme which was fed in the chip of the module. Programme was done according to the requirement of the water level of the hydroponic system. The flow diagram of solar operated hydroponic system shown in Fig. 4.

\section{Selection of seed rate}

Three Maize seed rates were selected to calculate the plant height, root length and chemical analysis. The seed rates were $600 \mathrm{~g}$, $750 \mathrm{~g}, 900 \mathrm{~g}$ per tray (Islam et al., 2016).

\section{Chemical analysis}

Chemical analysis was done to the hydroponic maize fodder on $10^{\text {th }}$ day to find out the Moisture content, Crude protein, Crude fiber, Ether extract and total ash according AOAC standards (AOAC, 1980 and Bakshi et al., 2017). After the Analysis date were recorded and compared between the treatments to find the best treatment according to the chemical analysis. The procedure for the estimation of these parameters as follows:

\section{Moisture content}

The moisture of fresh and dry fodder was determined by the process of hot air oven method

$\mathrm{MC}=\frac{W 2-W 1}{W 3}$

Where,

$\mathrm{MC}=$ Moisture content

$\mathrm{W} 1=$ Initial weight of sample $(\mathrm{g})$

$\mathrm{W} 2=$ Final weight of sample $(\mathrm{g})$ and

$\mathrm{W} 3=$ Weight of dried sample in grams

\section{Crude protein}

The crude protein in hydroponic maize fodder was determined by using micro Kjeldhal method

Protein $\%=\frac{T . V X 0.014 \times 100(\mathrm{ml}) \times 0.01 \times 100 \times 6.25}{\text { weight of sample }(\mathrm{g}) \text { Xaliquot used in distillation }(\mathrm{ml})}$

Where, $\mathrm{T} . \mathrm{V}=$ titre value

\section{Crude fiber}

The crude fiber of hydroponic maize fodder was determined by the sequential acid and alkali hydrolysis method using Fibra-plus apparatus

Crude fiber $(\%)=\frac{W 1-W 2}{W} X 100$

Where,

$\mathrm{W} 1=$ weight of the sample before ashing (g)

$\mathrm{W} 2=$ weight of the sample after ashing $(\mathrm{g})$ 


\section{Ether extract and total ash}

Ether extract was done using Soxhlet apparatus and principle involved was that when a known weight of feed was ignited to ash. The weight of ash thus obtained was expressed in terms of percentage.

\section{Results and Discussion}

The performance evaluation of power transmission system was conducted. The Arduino module controlled the on and off of the motor and solenoid valves. The time interval was given for 4 hours. By using foggers, the irrigation water supply for the fodder was good. Solenoid valves were installed in each compartment because motor pump which we selected could not able to build much pressure for the fogging, so solenoid valves operated the supply of water to each compartment separately.

Chemical analysis was done on $10^{\text {th }}$ day for the three seed rates $600 \mathrm{~g} /$ tray, $750 \mathrm{~g} /$ tray and $900 \mathrm{~g} /$ tray. The highest crude protein, crude fiber, ether extract, and total ash was observed in the seed rate $900 \mathrm{~g} /$ tray. The highest weight was also observed in $900 \mathrm{~g} /$ tray seed rate which was $5.15 \mathrm{~kg}$. Chemical analysis of hydroponic green fodder at different sed rate shown in Table 1.

Table.1 Chemical analysis of hydroponic green fodder at different sed rate

\begin{tabular}{|l|c|c|c|}
\hline Particulars & \multicolumn{3}{|c|}{ Seed rate (kg/tray) } \\
\hline Plant height & 600 & 750 & 900 \\
\hline Root length & 19.32 & 23.37 & 25.65 \\
\hline Total Weight per tray & 10.72 & 17.38 & 20.15 \\
\hline Dry matter (\%) & 3.51 & 4.38 & 5.15 \\
\hline Crude protein (\%) & 12.93 & 13.78 & 14.01 \\
\hline Ether Extract (\%) & 13.06 & 14.75 & 14.81 \\
\hline Crude fiber (\%) & 2.90 & 3.01 & 3.30 \\
\hline Total ash (\%) & 12.90 & 12.50 & 13.85 \\
\hline
\end{tabular}

Fig.1 Isometric view of Hydroponic stand
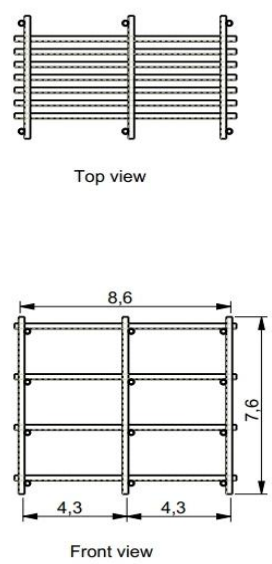

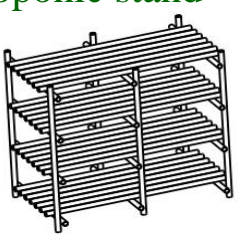

Isometric view

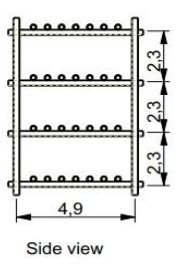


Table.2 Specifications of solar operated hydroponic green fodder production system

\begin{tabular}{|l|l|l|}
\hline Sl.No. & Parameters & specifications \\
\hline $\mathbf{1}$ & Shade net house & $150 \mathrm{ft}^{2}$ \\
\hline & (a) Area & $15 \times 10 \times 10$ \\
\hline & (b) Length $x$ breadth $x$ height $(\mathrm{ft})$ & $70 \% \mathrm{UV}$ protected \\
\hline $\mathbf{2}$ & (c) Shade net & \\
\hline & Bamboo framed hydroponic stand & $42.14 \mathrm{ft}^{2}$ \\
\hline & (a) Area & 4 and $8.6 \mathrm{ft} \times 4.9 \mathrm{ft} \times 7 \mathrm{ft}$ \\
\hline $\mathbf{3}$ & Solnumber of compartments and size & $80 \mathrm{~W}$ maximum power \\
\hline $\mathbf{4}$ & Battery & 40 Ah capacity \\
\hline $\mathbf{5}$ & Solar Charge Controller & Lead acid solar battery \\
\hline $\mathbf{6}$ & Arduino module & Maximum panel voltage $25 \mathrm{~V}$ \\
\hline $\mathbf{7}$ & Relay switch & $1,5 \mathrm{~V}$ \\
\hline $\mathbf{8}$ & Motor pump & $1,5 \mathrm{~V}$ \\
\hline $\mathbf{9}$ & Water tank & 140 Psi, 7-9 L/ min \\
\hline $\mathbf{1 0}$ & Hydroponic trays & $12 \mathrm{~V}$ DC motor \\
\hline $\mathbf{1 1}$ & Foggers & 200 Liters capacity \\
\hline $\mathbf{1 2}$ & Laterals & 48 \\
\hline $\mathbf{1 3}$ & Solenoid valves & 32 foggers \\
\hline & & 4 \\
\hline
\end{tabular}

Fig.2 Isometric view of Shade net house
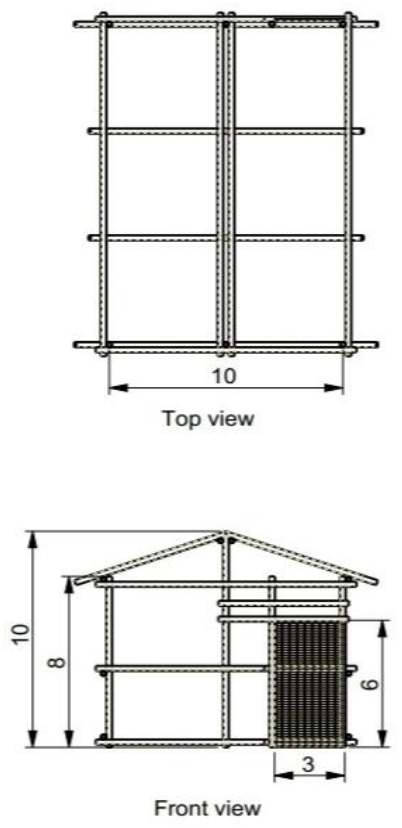
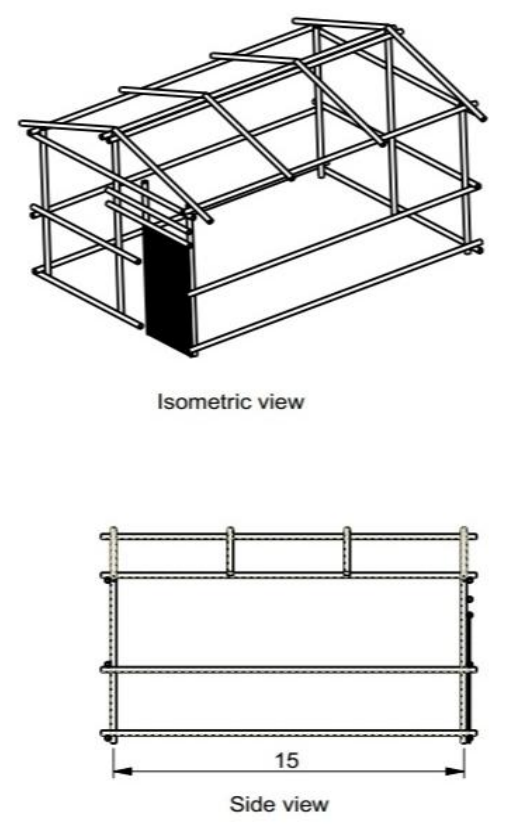
Fig.3 Shade net house and bamboo framed hydroponic stand with hydroponic trays

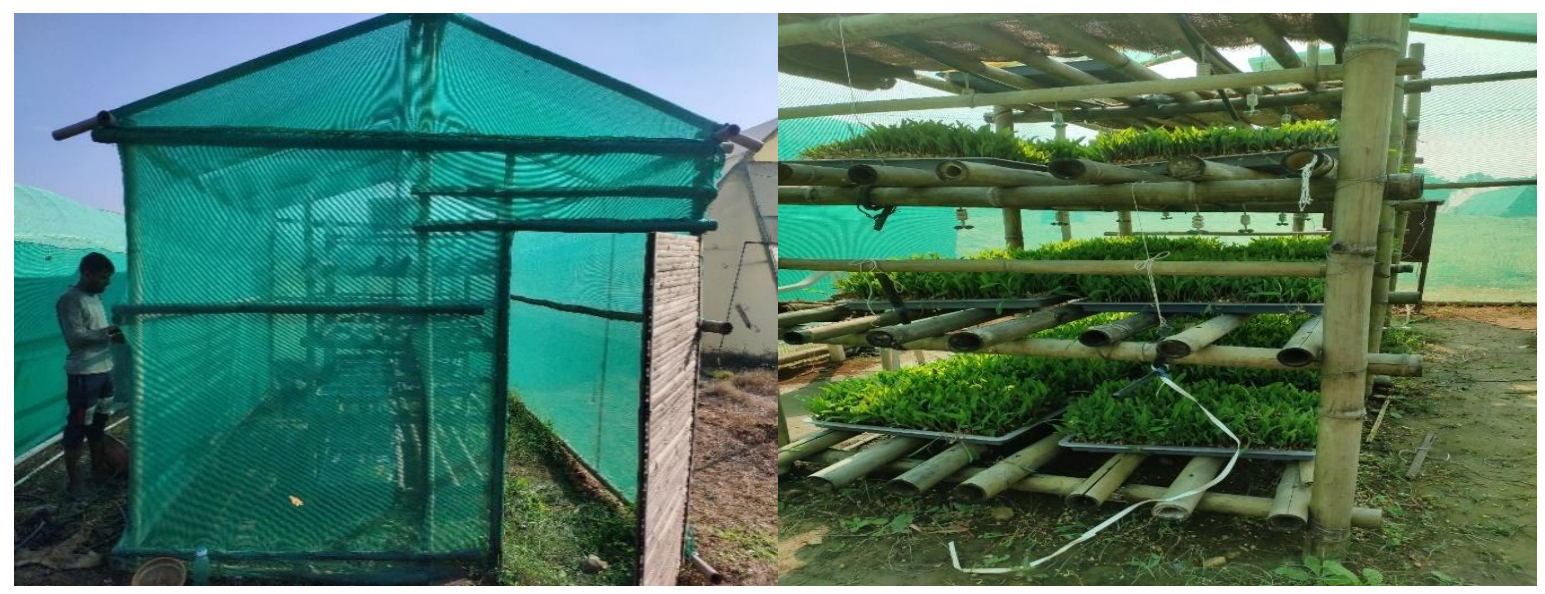

Fig.4 flow diagram of solar operated hydroponic system

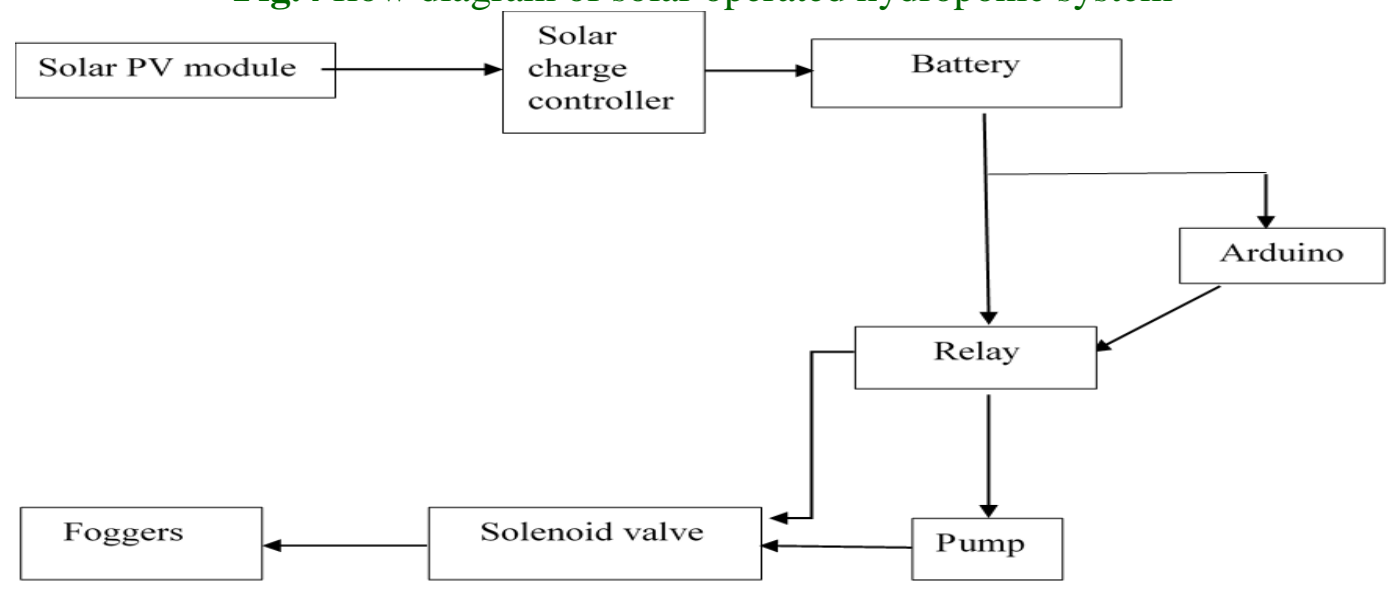

In conclusion, solar operated hydroponic system specially designed for green fodder. small and marginal farmers easily adopt this because whole structure was designed by locally available bamboo sticks. Arduino which was used for the automation controlled whole irrigation system of hydroponics. The specifications of solar operated hydroponic green fodder production system shown in Table 2.

The highest crude protein, dry matter, ether extract, crude fiber, total ash and weight per tray was observed in $900 \mathrm{~g}$ seed rate per tray as $14.81 \%, 14.01 \%, 3.30 \%, 13.85 \%, 2.90$ and $5.15 \mathrm{~kg} /$ tray. This was the best combination for the given tray size.

\section{Acknowledgments}

Authors gratefully acknowledge the support and facilities provided by the CTAE, MPUAT, Udaipur to carry out this study. They also acknowledge the assistance provided by Manas Bhamu and Vishal Deep in automation of system. They are also grateful to the anonymous reviewer for the useful suggestions, which improved quality of earlier version of this paper.

\section{References}

Anonymous 2019. 20 ${ }^{\text {th }}$ Livestock census. Ministry of Agriculture and Farmers Welfare GOI. Pp. 13-14.

AOAC, 1980, Official methods of analysis 
$10^{\text {th }}$ edition. Association of official Agricultural chemists, Washington, D.C.

Aruna, M., Ishwarya, K. and Anand, M.G.2018.Design and development of solar hydroponic system. International Journal of Intellectual Advancements and Research in Engineering Computations, 6: 1663-1668.

Bakshi, M. Wadhwa and Harinder P.S. Makka. 2017. Hydroponic fodder production a critical assessment. Animal feed resources information system, 48: 2-10.

Islam, R., Jalal, N. and Akbar, A. 2016. Effect of seed rate and water level on production and chemical analysis of hydroponic fodder. European Academic Research, 6: 67242-6753.

Jemimah, R., Gnanaraj P.T, and Muthuramalingham, T. 2015. Hydroponic green fodder production.
TANUVAS experience.

Kamat, R. and Kulkarni V. 2018. Design and development of solar assisted hydroponic maize fodder gadget. International Journal of Current Microbiology and Applied Sciences, 7(3):124-131.

Ramteke, R, Raindonasria, and Gendley, M.K. 2019. Hydroponic techniques for fodder production. Acta Scientific Nutritional Health, 3(5): 127-132.

Reddy, K. R., Kondapalli, K. and Rao, K. R. S 2012. Role of Hydroponics and Aeroponics in Soilless Culture in Commercial Food Production. Journal of Agricultural Science \& Technology: Pp. 26-35.

Sharma, N.K., Tiwari, P.K. and Sood, Y.R. 2012. Solar energy in India: Strategies, policies Perspectives and future potential. Renewable and Sustainable energy Reviews, 16(1): 933-941.

\section{How to cite this article:}

Manju, H. M., Manjeet Singh, K. K. Yadav and Bhakar, S. R. 2020. Development of Solar Operated Hydroponic Fodder Production System. Int.J.Curr.Microbiol.App.Sci. 9(11): 29362942. doi: https://doi.org/10.20546/ijcmas.2020.911.357 